\title{
Cytotoxic Effect of the Genus Sinularia Extracts on Human SCC25 and HaCaT Cells
}

\author{
Guey-Horng Wang, 1 Tzung-Han Chou, ${ }^{1}$ Rong-Jyh Lin, ${ }^{2}$ Jyh-Horng Sheu, ${ }^{3}$ \\ Shih-Hao Wang, ${ }^{4}$ and Chia-Hua Liang ${ }^{1}$ \\ ${ }^{1}$ Department of Cosmetic Science, Chia Nan University of Pharmacy and Science, Tainan 717, Taiwan \\ ${ }^{2}$ Department of Parasitology, Faculty of Medicine, Kaohsiung Medical University, Kaohsiung 807, Taiwan \\ ${ }^{3}$ Department of Marine Biotechnology and Resources, National Sun Yat-Sen University, Kaohsiung 804, Taiwan \\ ${ }^{4}$ Graduate Institute of Pharmaceutical Chemistry, China Medical University, Taichung 404, Taiwan
}

Correspondence should be addressed to Chia-Hua Liang, tinna_ling@yahoo.com.tw

Received 14 February 2008; Revised 2 June 2008; Accepted 4 July 2008

Recommended by Peter O’Brien

Soft corals of the genus Sinularia are being increasingly adopted to treat a wide variety of disease processes. However, the mechanism underlying its activity against human oral cancer cells is poorly understood. This study evaluates the cyototoxicity effects of the genus Sinularia extracts (S. grandilobata, S. parva, S. triangula, S. scabra, S. nanolobata and S. gibberosa) by SCC25 and $\mathrm{HaCaT}$ cells. The cell adhesion assay indicates that extracts reduce the cell attachment. Extracts exhibit a dose-dependent cytotoxic effect using MTS assay.Treatment of extracts to observe the morphological alterations in cells, membrane blebbing, nuclear condensation, and apoptotic bodies is demonstrated. Flow cytometry shows that extracts sensitized the cells in the $\mathrm{G}_{0} / \mathrm{G}_{1}$ and $\mathrm{G}_{2} / \mathrm{M}$ phases with a concomitant significantly increased sub- $\mathrm{G}_{1}$ fraction, suggesting cell death by apoptosis. Extracts of the genus Sinularia thus apparently cause apoptosis of SCC25 and HaCaT cells, and warrant further research investigating the possible antioral cancer compounds in these soft corals.

Copyright (c) 2009 Guey-Horng Wang et al. This is an open access article distributed under the Creative Commons Attribution License, which permits unrestricted use, distribution, and reproduction in any medium, provided the original work is properly cited.

\section{Introduction}

Medicinal marine organisms are most appropriate for pharmacological research and drug development, since their constituents can be employed not only as therapeutic agents, but also as starting materials or models for synthesis of drugs of pharmacologically active compounds. Many efforts have recently been made to identify new therapeutic drugs against cancer, especially using novel biologically active compounds from natural marine organisms [1].

Coral growths are a few hundred million years old. Pressure from the natural selection has led corals to develop a delicate chemical balance for self protection. Soft corals (coelenterata, octocorallia, alcyonaceae) are a rich source of steroids and terpenoids $[2,3]$, and most isolated diterpenes are cembranolides [4]. Hence, such chemical toxins may exhibit various biological activities, such as antitumor, antimicrobial, and HIV-inhibitory activity. The authors have previously reported various bioactive metabolites from marine organisms, including sesquiterpenoids, diterpenoids, and steroids [5-8]. Many of these metabolites have been found to be cytotoxic, or to possess other biological activities [9-11]. However, little thorough cytotoxicity research has been performed on these soft corals. Therefore, this study investigates the cytotoxic mechanism of the organic extracts of six Taiwanese soft corals, namely Sinularia grandilobata, $S$. parva, S. triangula, S. scabra, S. nanolobata, and S. gibberosa.

Oral cancer is a significant global public health problem, causing high morbidity and mortality that have not improved in decades [12]. Squamous cell carcinomas (SCCs) are the most common type of oral cancer. Although new operative techniques and adjuvant measures including chemotherapy and radiotherapy against oral SCCs have progressed, patients with advanced oral SCCs still have a 
poor prognosis, with a 5-year survival rate of $65 \%$ [13]. Thus, new anticancer drugs are required to enhance current protocols for diagnosis and treatment of SCCs.

Apoptosis is an important phenomenon in exerting antitumor response to cancer therapy and is also a valuable marker for predicting tumor response following anticancer treatment. Cell death can be apoptotic, or result from morphological changes such as membrane blebbing, cell shrinkage, chromatin condensation, and nuclear fragmentation with formation of apoptotic bodies. Translocation of membrane phosphatidylserine and sub- $\mathrm{G}_{1}$ fraction is a form of programmed cell death that occurs naturally in cells and can be beneficial to cancer therapy [14]. Ability to manipulate the machinery of cell death is an obvious goal of medical research, and effect on regulation of apoptosis might lead to new possibilities for oral cancer treatment [15]. Hence, this study evaluated the induction of cell apoptosis of the genus Sinularia extracts on human SCC25 cells and premalignant keratinocytes ( $\mathrm{HaCaT})$.

\section{Materials and Methods}

2.1. Material. The six soft corals of the genus Sinularia including S. grandilobata, S. parva, S. triangula, S. scabra, $S$. nanolobata and $S$. gibberosa were collected by hand via scuba along the coast of Southern Taiwan, at a depth of $10-15 \mathrm{~m}$ and were stored in a freezer until extraction. A voucher specimen was deposited at the Department of Marine Biotechnology and Resources, National Sun Yat-Sen University, Taiwan.

2.2. Preparation of Extracts. The tissues of six soft corals of the genus Sinularia were freeze-dried and then exhaustively extracted with ethyl acetate (two times). The ethyl acetate extracts were then filtered and concentrated under vacuum to provide a brownish semisolid crude extract. Organic extracts were dissolved at a concentration of $10 \mathrm{mg} / \mathrm{mL}$ in $100 \%$ dimethyl sulfoxide (DMSO) at stock solution. Stock solution was diluted to the desired final concentrations with growth medium just before use. The final DMSO concentration did not exceed $0.1 \%$.

2.3. Cell Lines and Cell Culture. Human oral squamous cell carcinoma (SCC25) cells was purchased from the American Type Culture Collection (Rockville, Md, USA). Human premalignant keratinocytic cells $(\mathrm{HaCaT})$ were a kind gift from Hamm-Ming Sheu (National Cheng Kung University Medical College, Tainan, Taiwan). Cells were cultured in medium supplemented with $10 \%$ fetal bovine serum (Hazelton Product, Denver, Pa, USA) and $1 \%$ penicillinstreptomycin at $37^{\circ} \mathrm{C}$ in $5 \% \mathrm{CO}_{2}$; specifically SCC25 cells in Dulbecco's Modified Eagle's Medium/F12 medium and HaCaT cells in Dulbecco's Modified Eagle's Medium medium (GIBCO, Grand Island, NY, USA).

2.4. Cell Adhesion Assay. Cells $\left(1.5 \times 10^{5}\right.$ cells/well $)$ were subcultured into 24 -well plates and incubated. After 24 hours of incubation, the medium was changed by adding DMEM/F12 or DMEM containing $1 \%$ bovine serum albumin (BSA) and with or without serial concentrations ofextracts for 18 hours. Attached cell number was estimated by means of a DNA carmine-based colorimetric method [16]. Briefly, cells were fixed with $100 \%$ methanol, dried and stained with alcoholic/ $\mathrm{HCl}$ carmine. Colorant was extracted with $0.01 \mathrm{~N} \mathrm{NaOH}$, and absorbance was determined at $540 \mathrm{~nm}$. The cell number was estimated using a titration curve of cell density (SCC25: $y=5 \times 10^{-8} x+0.0143 ; R^{2}=0.9849$; HaCaT: $\left.y=3 \times 10^{-8} x+0.0019 ; R^{2}=0.9904\right)$, and results were given as a percentage of the cell number with respect to control cells. For the titration curve, cells were plated at densities ranging form $1 \times 10^{3}$ to $7 \times 10^{5}$ cells/well in 24-well plates using serial dilutions of concentrated cell suspensions. After adhesion, some wells of each density were harvested with trypsin and cells were counted in a hemacytometer; meanwhile, parallel cultures were fixed and stained as described before [16]. A relationship between the cell number and resultant absorbance after the colorant extraction, for each cell density, was accomplished and celldensity titration-curve construction, which measured cell adhesion.

2.5. Growth-Inhibition Assay. Cells $\left(1.5 \times 10^{4}\right.$ cells/well $)$ were seeded in each $100 \mu \mathrm{L}$ of 96 -well multidishes for at least 24 hours prior to use. The cells were treated with serial concentrations of extracts for 18 hours. After replacing new medium, the effects on cell growth were determined by a colorimetric tetrazolium MTS [3-(4,5-dimethyl-thiazol-2-yl)-5-(3-carbox-ymethoxyphenyl)-2-(4sulfophenyl)-2H-tetrazolium, inner salt] assay according to the manufacturer's procedure (CellTiter $96 \mathrm{AQ}$, Promega, Madison, Wis, USA). The absor-bance at $490 \mathrm{~nm}$ was measured by a spectrophotometer (Dydatech, Alexandria, Va, USA). Values are expressed as the percentage of mean cell viability is relative to the untreated cultures. The $\mathrm{IC}_{50}$ and $\mathrm{IC}_{80}$ were calculated from the drug concentration that induced $50 \%$ and $80 \%$ of cell survival rate. All determinations were performed in triplicate and statistically analyzed by Student's $t$-test.

2.6. Determination of Morphological Changes of Cells. Cells $\left(1.5 \times 10^{5}\right.$ cells/well $)$ were plated in 24 -well plates then treated with $\mathrm{IC}_{50}$ concentrations of extracts for 18 hours. After incubation, the medium was removed and cells were fixed in $4 \%$ paraformaldehyde and permeabilized in saponin $(0.1 \% \mathrm{v} / \mathrm{v}$ in PBS-BSA). Morphological analysis was performed using phase contrast inverted light microscope (Nikon, TE2000-U, Japan) at $200 \times$ magnification. To assess specific apoptosis, Hoechst $(1 \mu \mathrm{g} / \mathrm{mL})$ (Sigma, USA) was added to each well and further incubated at $37^{\circ} \mathrm{C}$ for 30 minutes in the dark. Living and apoptotic cells were visualized through blue filter of fluorescence inverted microscope (Nikon, TE2000-U, Japan) at 200× magnification.

2.7. Assessment of Cell-Cycle Distribution and Apoptotic Cells by Flow Cytometry. Cells $\left(1.5 \times 10^{5}\right)$ were seeded in 24well plates and incubated with or without $\mathrm{IC}_{50}$ and $\mathrm{IC}_{80}$ 
TABLE 1: Percentage of SCC25 and HaCaT cells adhesion by different concentrations of the genus Sinularia extracts.

\begin{tabular}{|c|c|c|c|c|c|c|c|}
\hline Cell lines & Treatment $(\mu \mathrm{g} / \mathrm{mL})$ & No. 1 & 2 & 3 & 4 & 5 & 6 \\
\hline \multirow{8}{*}{ SCC25 } & 0 & $100.0 \pm 0.9$ & $100.0 \pm 1.0$ & $100.0 \pm 0.6$ & $100.0 \pm 3.4$ & $100.0 \pm 2.2$ & $100.0 \pm 1.0$ \\
\hline & 1 & $74.7 \pm 1.0$ & $118.5 \pm 0.9$ & $105.1 \pm 8.7$ & $94.1 \pm 5.8$ & $110.9 \pm 7.7$ & $101.7 \pm 6.7$ \\
\hline & 5 & $70.4 \pm 1.9$ & $71.3 \pm 4.8$ & $79.7 \pm 2.9$ & $94.0 \pm 1.9$ & $70.4 \pm 6.7$ & $94.9 \pm 2.5$ \\
\hline & 10 & $70.4 \pm 1.9$ & $70.4 \pm 3.8$ & $60.3 \pm 3.8$ & $81.4 \pm 2.9$ & $70.4 \pm 1.9$ & $88.2 \pm 8.6$ \\
\hline & 20 & $71.3 \pm 2.9$ & $69.6 \pm 6.7$ & $59.5 \pm 6.7$ & $99.1 \pm 3.8$ & $71.3 \pm 8.6$ & $88.1 \pm 8.5$ \\
\hline & 40 & $70.4 \pm 3.8$ & $66.2 \pm 2.9$ & $60.3 \pm 3.8$ & $81.4 \pm 2.9$ & $71.3 \pm 0.9$ & $81.6 \pm 2.9$ \\
\hline & 60 & $53.5 \pm 7.3$ & $38.3 \pm 0.1$ & $51.0 \pm 2.9$ & $51.0 \pm 6.7$ & $66.2 \pm 2.9$ & $63.7 \pm 1.9$ \\
\hline & 100 & $41.7 \pm 1.9$ & $21.5 \pm 0.3$ & $44.3 \pm 0.9$ & $53.5 \pm 1.5$ & $55.2 \pm 3.8$ & $49.3 \pm 8.7$ \\
\hline \multirow{8}{*}{$\mathrm{HaCaT}$} & 0 & $100.0 \pm 1.8$ & $100.0 \pm 1.6$ & $100.0 \pm 3.4$ & $100.0 \pm 0.9$ & $100.0 \pm 6.2$ & $100.0 \pm 5.4$ \\
\hline & 1 & $78.4 \pm 1.8$ & $89.9 \pm 2.3$ & $95.7 \pm 2.5$ & $99.3 \pm 3.7$ & $97.4 \pm 4.5$ & $100.0 \pm 2.7$ \\
\hline & 5 & $80.4 \pm 0.9$ & $91.9 \pm 3.7$ & $97.5 \pm 3.4$ & $95.9 \pm 0.9$ & $88.9 \pm 7.2$ & $84.3 \pm 5.3$ \\
\hline & 10 & $79.1 \pm 0.9$ & $83.1 \pm 7.6$ & $93.8 \pm 0.1$ & $88.6 \pm 1.8$ & $86.3 \pm 9.8$ & $74.5 \pm 1.8$ \\
\hline & 20 & $80.4 \pm 8.2$ & $83.8 \pm 8.6$ & $80.9 \pm 0.8$ & $79.9 \pm 2.8$ & $82.4 \pm 1.8$ & $69.3 \pm 1.8$ \\
\hline & 40 & $77.7 \pm 2.9$ & $81.1 \pm 1.8$ & $74.7 \pm 2.5$ & $75.2 \pm 3.7$ & $79.8 \pm 1.8$ & $69.3 \pm 5.4$ \\
\hline & 60 & $75.0 \pm 4.6$ & $44.7 \pm 7.4$ & $63.6 \pm 0.9$ & $75.9 \pm 2.0$ & $73.9 \pm 1.7$ & $70.6 \pm 0.5$ \\
\hline & 100 & $64.2 \pm 8.8$ & $43.3 \pm 9.3$ & $60.5 \pm 0.2$ & $61.8 \pm 2.9$ & $45.8 \pm 4.4$ & $51.7 \pm 4.5$ \\
\hline
\end{tabular}

(i) Results are the average of three independent experiments.

(ii) S. grandilobata, 1 ; S. parva, 2; S. triangula, 3; S. scabra, 4; S. nanolobata, 5; S. gibberosa, 6.

concentrations of extracts for 18 hours. Cells were then fixed in $70 \%$ ethanol/PBS, pelleted and resuspended in buffer containing $200 \mu \mathrm{g} / \mathrm{mL}$ RNase A and $0.01 \mathrm{mg} / \mathrm{mL}$ propidium iodide (PI). The cells were incubated in the dark for 15 minutes at room temperature and then analyzed by FACScan Flow Cytometer (Becton Dickinson, San Jose, Calif, USA). The cell distribution in each phase of the cell cycle was determined using WinMDI software, including $\operatorname{subG}_{1}$-peak of apoptotic cells.

2.8. Statistical Analysis. To evaluate the statistical significance of the difference of all the values, statistical analysis was performed on the means of the triplicates of at least three independent experiments using a two-tailed Student's $t$-test. $P$ values less than .05 were considered significant for all tests.

\section{Results}

3.1. Influence of the Genus Sinularia Extracts on Cells Adhesion. To investigate six soft corals of the genus Sinularia extracts (S. grandilobata, S. parva, S. triangula, S. scabra, S. nanolobata and S. gibberosa) inhibited SCC25 and $\mathrm{HaCaT}$ cells adhesion, cells were treated with different concentrations $(0,1,5,10,20,40,60$, and $100 \mu \mathrm{g} / \mathrm{mL})$ of extracts for 18 hours, and the cell adhesion assay was performed. Cells remained firmly attached to the culture dish at low concentrations $(<40 \mu \mathrm{g} / \mathrm{mL})$ of extract, and a cytotoxic effect was not observed until almost $70 \%$ as indicated in Table 1. The number of attached cells decreased with rising concentrations of extracts $(60-100 \mu \mathrm{g} / \mathrm{mL})$. This reveals that high concentration of extracts may affect cell adhesion on collagen fibers, thus increasing cell cytotoxicity. The cell adhesion assay shows that the extract of S. parva was the most effective inhibitor of cell survival and adhesion. However, cell adhesion alone does not indicate that a cell is alive. An enzymatic test such as MTS assay is required to further evaluate the effect of extracts on cell cytotoxicity.

3.2. Growth-Inhibition Assay Effect of the Genus Sinularia Extracts. MTS assay was conducted to examine the relationship between concentrations of the genus Sinularia extracts and the cytotoxicity of SCC25 and HaCaT cells. Cells were treated with extracts at increasing concentrations of $0-100 \mu \mathrm{g} / \mathrm{mL}$ for 18 hours, and the percentage of cell viability was analyzed. Organism extracts were dissolved in DMSO, and a parallel experiment demonstrated that the final concentration of DMSO in the medium $(0.1 \%)$ did not produce any impact on SCC25 and HaCaT cell cytotoxicity (data not shown). As revealed in Figure 1, all of the extracts inhibited SCC25 and HaCaT cell growth in a dose-dependent manner. The concentrations of extracts causing $50 \%$ and $80 \%$ cell growth inhibition $\left(\mathrm{IC}_{50}\right.$ and $\mathrm{IC}_{80}$ ) were determined and are presented in Table 2. The $\left(\mathrm{IC}_{50}\right)$ s of S. grandilobata, S. parva, S. triangula, S. scabra, S. nanolobata and S. gibberosa were approximately 36.71, $34.0,32.2,38.9,31.4$, and $39.1 \mu \mathrm{g} / \mathrm{mL}$ for SCC25, and 33.6 , $30.3,49.1,26.8,22.6$, and $32.9 \mu \mathrm{g} / \mathrm{mL}$ for HaCaT cells. The $\left(\mathrm{IC}_{80}\right)$ s of six extracts were about 75.9, 71.3, 68.7, 93.0, 70.7, and $127.1 \mu \mathrm{g} / \mathrm{mL}$ for SCC25, and 64.7, 54.2, 80.6, 70.5, 62.5, and $74.7 \mu \mathrm{g} / \mathrm{mL}$ for HaCaT cells. The cell cytotoxicity assay demonstrates that $S$. parva and S. nanolobata exhibited the highest potency in inhibiting cell growth, and the results are corresponded to observe with cell adhesion assay.

3.3. Impact of the Genus Sinularia Extracts on Cell Morphology Changes. A morphological study of SCC25 and HaCaT cells 




(a)

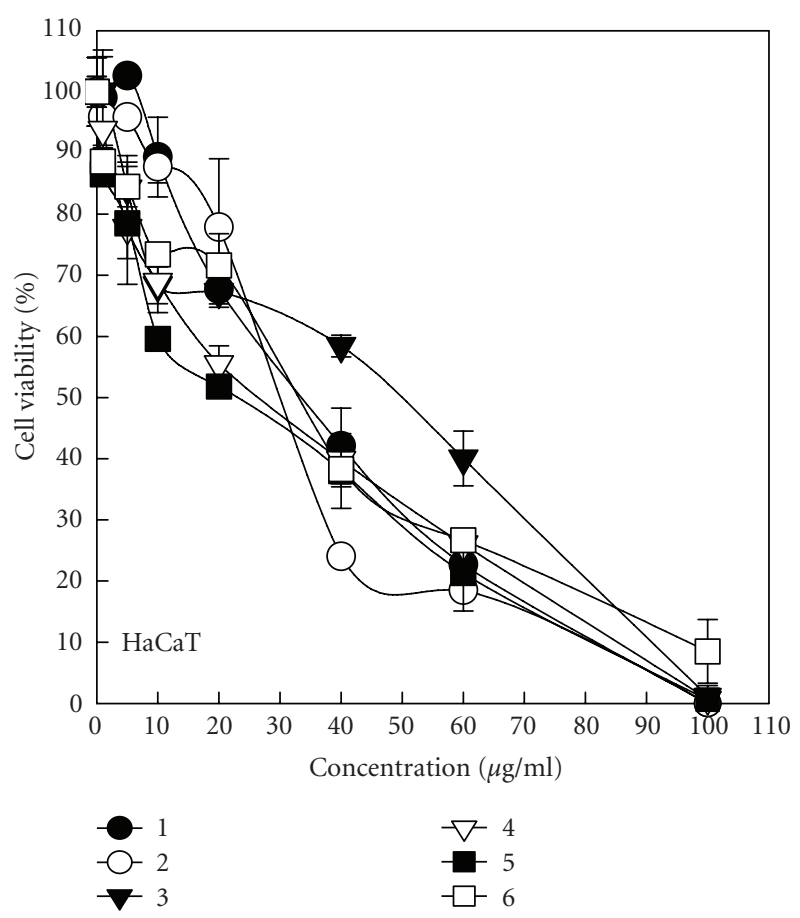

(b)

FIgURE 1: Dose-dependency effects of the genus Sinularia extracts on the cell growth inhibition of SCC25 and HaCaT cells. Percentage of viable in cells treated with $0-100 \mu \mathrm{g} / \mathrm{mL}$ concentrations of Sinularia extracts for 18 hours and determined by MTS assay. Data are means \pm

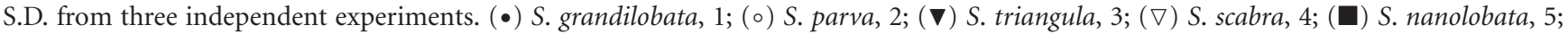
and ( $\square)$ S. gibberosa, 6 .

TABLe 2: Cell viability of the genus Sinularia extracts in SCC25 and HaCaT cells.

\begin{tabular}{|c|c|c|c|c|}
\hline \multirow{3}{*}{ No. } & \multicolumn{4}{|c|}{ Cell lines } \\
\hline & \multicolumn{2}{|c|}{ SCC25 } & \multicolumn{2}{|c|}{$\mathrm{HaCaT}$} \\
\hline & $\mathrm{IC}_{50}(\mu \mathrm{g} / \mathrm{mL})$ & $\mathrm{IC}_{80}(\mu \mathrm{g} / \mathrm{mL})$ & $\mathrm{IC}_{50}(\mu \mathrm{g} / \mathrm{mL})$ & $\mathrm{IC}_{80}(\mu \mathrm{g} / \mathrm{mL})$ \\
\hline 1 & $36.7 \pm 5.6$ & $75.9 \pm 3.3$ & $33.6 \pm 3.1$ & $64.7 \pm 1.8$ \\
\hline 2 & $34.0 \pm 2.5$ & $71.3 \pm 0.9$ & $30.3 \pm 4.2$ & $54.2 \pm 2.9$ \\
\hline 3 & $32.2 \pm 2.9$ & $68.7 \pm 1.8$ & $49.1 \pm 2.3$ & $80.6 \pm 3.7$ \\
\hline 4 & $38.9 \pm 1.5$ & $93.0 \pm 4.2$ & $26.8 \pm 5.0$ & $70.5 \pm 3.6$ \\
\hline 5 & $31.4 \pm 6.8$ & $70.7 \pm 3.1$ & $22.6 \pm 2.8$ & $62.5 \pm 4.8$ \\
\hline 6 & $39.1 \pm 1.9$ & $127.1 \pm 8.7$ & $32.9 \pm 3.7$ & $74.7 \pm 1.5$ \\
\hline
\end{tabular}

(i) Results are the average of three independent experiments.

(ii) S. grandilobata, $1 ;$ S. parva, 2; S. triangula, 3; S. scabra, 4; S. nanolobata, 5; S. gibberosa, 6.

was undertaken to obtain additional information about the cytotoxicity of soft corals of the genus Sinularia extracts. Rounding was observed following incubation with extract under concentration of $\mathrm{IC}_{50}$ for 18 hours to observe the morphological alterations in the cells. Some sensitive cells were then detached from the surface, and membrane blebbing was shown by using a phase-contrast-inverted microscope. The typical nuclear condensation, nuclear fragmentation, nuclear shrinking, and apoptotic bodies of the cells were then demonstrated by Hoechst staining (see Figure 2). Results of these experiments indicate that the genus Sinularia extracts cause apoptosis of human SCC25 and HaCaT cells.
3.4. Influence of the Genus Sinularia Extracts on Cell-Cycle Distribution and Apoptosis. The cell cycle distribution of SCC25 and HaCaT cells was analyzed with flow cytometry after exposure to the genus Sinularia extracts (see Figure 3). Results of treatment of cells with $\mathrm{IC}_{50}$ and $\mathrm{IC}_{80}$ concentrations of extracts reveal that the main character of apoptosis is the cleavage of nuclear DNA into multiple fragments and reflected $G_{0} / G_{1}$ and $S-G_{2} / M$ phase together with a dose-dependent increase in sub- $G_{1}$ phase (corresponding to apoptotic cells). As shown in Table 3, the percentage of $\mathrm{G}_{0} / \mathrm{G}_{1}, \mathrm{~S}$, and $\mathrm{G}_{2} / \mathrm{M}$ phases in SCC25 cells incubated with extracts $\left(\mathrm{IC}_{80}\right)$ for 18 hours was, respectively, 23.7-77.2\%, 
TABle 3: The changes of cell cycle distribution of the genus Sinularia extracts in SCC25 and HaCaT cells.

\begin{tabular}{|c|c|c|c|c|c|c|c|c|c|c|}
\hline \multirow{2}{*}{ Cell lines } & \multirow{2}{*}{ No. } & \multirow{2}{*}{ Treatment $(\mu \mathrm{g} / \mathrm{mL})$} & \multicolumn{2}{|c|}{ Sub-G $G_{1}$ phase } & \multicolumn{2}{|c|}{$\mathrm{G}_{0} / \mathrm{G}_{1}$ phase } & \multicolumn{2}{|c|}{ S phase } & \multicolumn{2}{|c|}{$\mathrm{G}_{2} / \mathrm{M}$ phase } \\
\hline & & & Mean & $\%$ & Mean & $\%$ & Mean & $\%$ & Mean & $\%$ \\
\hline \multirow{13}{*}{ SCC25 } & Control & 0 & 1.0 & 100.0 & 52.3 & 100.0 & 19.8 & 100.0 & 27.2 & 100.0 \\
\hline & \multirow{2}{*}{1} & $\mathrm{IC}_{50}$ & 32.5 & 3250.0 & 37.7 & 72.1 & 16.5 & 83.3 & 13.8 & 50.7 \\
\hline & & $\mathrm{IC}_{80}$ & 64.1 & 6410.0 & 21.9 & 41.9 & 7.3 & 36.9 & 6.8 & 25.0 \\
\hline & \multirow{2}{*}{2} & $\mathrm{IC}_{50}$ & 18.7 & 1870.0 & 46.8 & 89.4 & 15.7 & 79.3 & 19.8 & 72.8 \\
\hline & & $\mathrm{IC}^{80}$ & 58.9 & 5890.0 & 24.1 & 46.1 & 8.3 & 41.9 & 8.8 & 32.4 \\
\hline & \multirow{2}{*}{3} & $\mathrm{IC}_{50}$ & 23.6 & 2360.0 & 54.3 & 103.8 & 12.2 & 61.6 & 10.5 & 38.6 \\
\hline & & $\mathrm{IC}^{80}$ & 69.8 & 6980.0 & 18.6 & 35.6 & 6.8 & 34.4 & 4.8 & 17.6 \\
\hline & \multirow{2}{*}{4} & $\mathrm{IC}_{50}$ & 33.4 & 3340.0 & 37.7 & 72.1 & 14.4 & 72.7 & 14.8 & 54.4 \\
\hline & & $\mathrm{IC}_{80}$ & 80.1 & 8010.0 & 13.4 & 25.6 & 3.6 & 18.2 & 3.1 & 11.4 \\
\hline & \multirow{2}{*}{5} & $\mathrm{IC}^{50}$ & 24.3 & 2430.0 & 51.1 & 97.7 & 12.5 & 63.1 & 12.5 & 46.0 \\
\hline & & $\mathrm{IC}_{80}$ & 36.8 & 3680.0 & 40.4 & 77.2 & 12.8 & 64.6 & 10.3 & 37.9 \\
\hline & \multirow{2}{*}{6} & $\mathrm{IC}^{50}$ & 33.7 & 3370.0 & 32.8 & 62.7 & 15.5 & 78.3 & 18.3 & 67.3 \\
\hline & & $\mathrm{IC}_{80}$ & 79.6 & 7960.0 & 12.4 & 23.7 & 4.4 & 22.2 & 3.6 & 13.2 \\
\hline \multirow{13}{*}{$\mathrm{HaCaT}$} & Control & 0 & 0.8 & 100.0 & 59.5 & 100.0 & 16.2 & 100 & 23.7 & 100.0 \\
\hline & \multirow{2}{*}{1} & $\mathrm{IC}^{50}$ & 35.3 & 4412.5 & 34.3 & 57.6 & 13.1 & 80.9 & 16.7 & 70.5 \\
\hline & & $\mathrm{IC}_{80}$ & 69.4 & 8675.0 & 6.7 & 11.3 & 7.9 & 48.8 & 16.1 & 67.9 \\
\hline & \multirow{2}{*}{2} & $\mathrm{IC}_{50}$ & 19.4 & 2425.0 & 42.8 & 71.9 & 17.8 & 109.9 & 20.3 & 85.7 \\
\hline & & $\mathrm{IC}_{80}$ & 52.3 & 6537.5 & 15.3 & 25.7 & 15.1 & 93.2 & 17.4 & 73.4 \\
\hline & \multirow{2}{*}{3} & $\mathrm{IC}_{50}$ & 25.1 & 3137.5 & 45.2 & 76.0 & 16.4 & 101.2 & 13.9 & 58.6 \\
\hline & & $\mathrm{IC}^{80}$ & 56.1 & 7012.5 & 13.2 & 22.2 & 16.1 & 100 & 15.1 & 63.7 \\
\hline & \multirow{2}{*}{4} & $\mathrm{IC}^{50}$ & 39.1 & 4887.5 & 38.2 & 64.2 & 13.1 & 80.9 & 9.6 & 40.5 \\
\hline & & $\mathrm{IC}_{80}$ & 71.3 & 8912.5 & 8.1 & 13.6 & 9.9 & 61.1 & 10.9 & 46.0 \\
\hline & \multirow{2}{*}{5} & $\mathrm{IC}_{50}$ & 35.8 & 4475.0 & 35.4 & 59.5 & 15.4 & 95.1 & 13.8 & 58.2 \\
\hline & & $\mathrm{IC}_{80}$ & 58.9 & 7362.5 & 11.9 & 20.0 & 14.3 & 88.3 & 15.1 & 63.7 \\
\hline & \multirow[t]{2}{*}{6} & $\mathrm{IC}^{50}$ & 57.4 & 7175.0 & 10.2 & 17.1 & 12.8 & 79.0 & 19.7 & 83.1 \\
\hline & & $\mathrm{IC}_{80}$ & 72.9 & 9112.5 & 5.5 & 9.2 & 8.3 & 51.2 & 13.3 & 56.1 \\
\hline
\end{tabular}

(i) S. grandilobata, 1; S. parva, 2; S. triangula, 3; S. scabra, 4; S. nanolobata, 5; S. gibberosa, 6.

18.2-64.6\%, and $11.4-37.9 \%$ less than those in control cells. The sub-G $\mathrm{G}_{1}$ fraction of apoptotic SCC25 cells following incubation with $\left(\mathrm{IC}_{80}\right)$-treated cells was around 36.8-79.6 times that of control cells. The percentage of sub- $G_{1}$ phases in $\left(\mathrm{IC}_{80}\right)$-treated $\mathrm{HaCaT}$ cells was approximately 65.3-91.1 times that in untreated control cells. The $\mathrm{G}_{0} / \mathrm{G}_{1}$ and $\mathrm{G}_{2} / \mathrm{M}$ phase fractions were, respectively, about $9.2-25.7 \%$ and $46.0-76.4 \%$ less in the $\left(\mathrm{IC}_{80}\right)$-treated cells than in the control cells, and not much change in the S phase populations. The apoptotic cell death induced by treatment with Sinularia extracts by flow cytometry was thus very similar to that seen with Hoechst staining (see Figure 2). These results show that the genus Sinularia extracts-mediated inhibition of SCC25 and $\mathrm{HaCaT}$ cells viability might predominantly induce cells from the $G_{0} / G_{1}$ and $G_{2} / M$ phases to apoptosis.

\section{Discussion}

Oral cancer, which is one of the most disfiguring cancers, may lead to facial distortion. It is also known to exhibit field cancerization, resulting in development of second primary tumors [12]. Consequently, the development of new antioral cancer drugs, and study of their medicinal value, has become highly significant. The marine environment is a major reservoir of bioactive natural products with potential biomedical application; several marine natural products are seen as potential sources of therapeutic agents for the treatment of multiple disease categories. The majority of marine natural products and their derivatives are formed from invertebrates including soft corals, sponges, tunicates, mollusks, or bryozoans and are currently in advanced preclinical evaluation [1]. However, relatively few attempts have been made to explore resources of structurally unique chemistry for cytotoxic mechanism. This study presents the action mechanism of soft corals of the genus Sinularia extracts (S. grandilobata, S. parva, S. triangula, S. scabra, $S$. nanolobata and $S$. gibberosa) in the most common type of human oral squamous cell carcinomas SCC25 cells and human premalignant keratinocytes $\mathrm{HaCaT}$ cells. The cell adhesion and cell viability assays demonstrate the cytotoxicity effects of six extracts on both cells. Extracts induced morphological changes of chromatin condensation, DNA fragmentation, and sub- $G_{1}$ peak in a DNA histogram of SCC25 and HaCaT cells, indicating cell death by apoptosis. 


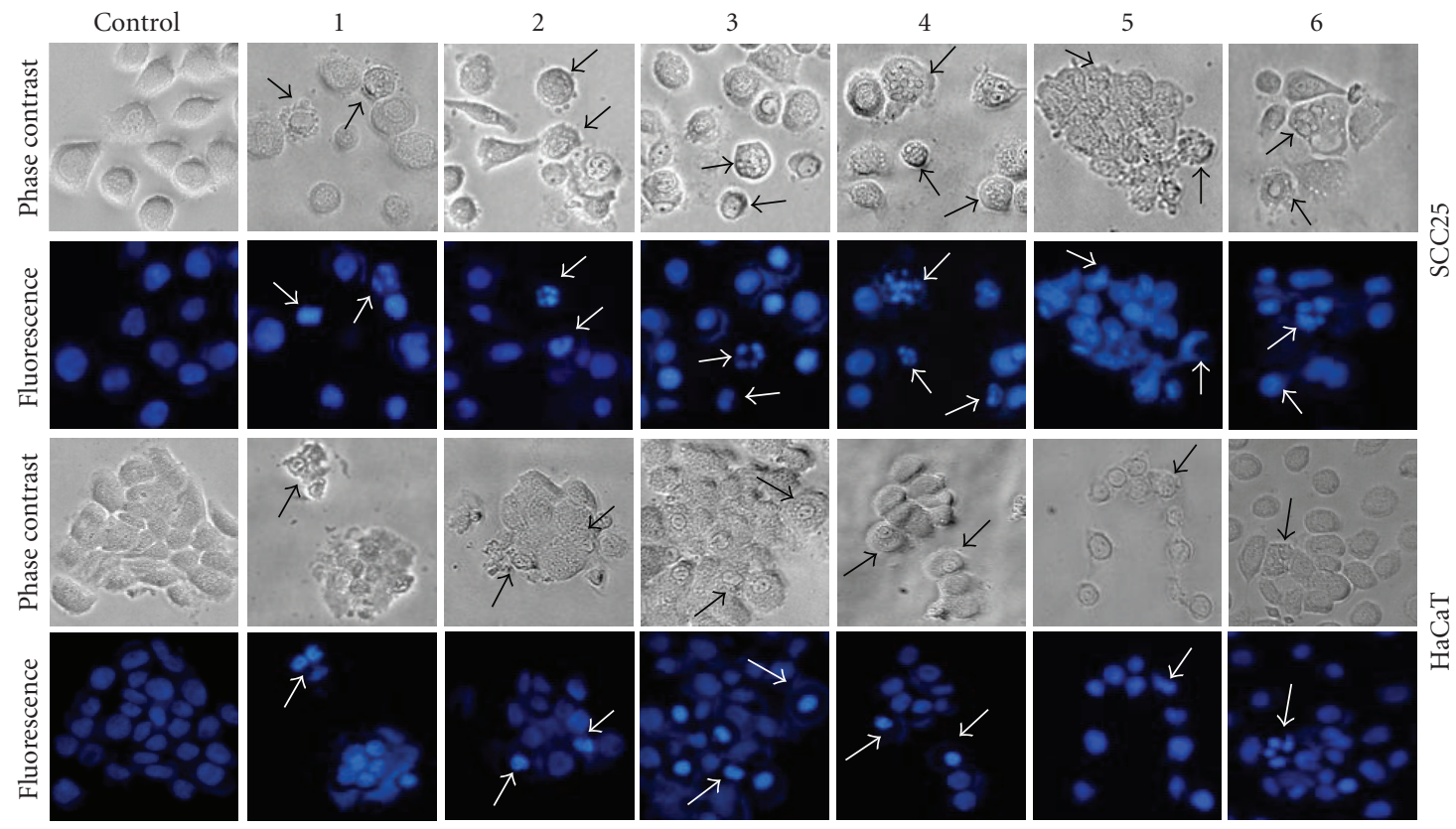

Figure 2: Morphological changes in SCC25 and HaCaT cells after the genus Sinularia extracts treatment. A constant concentration of extracts $\left(\mathrm{IC}_{50}\right)$ was added to the cells for 18 hours. The change was inspected by a phase-contrast-inverted microscopy. The cells were then fixed in $4 \%$ paraformaldehyde and DNA stained with Hoechst. The nuclei of the cells were visualized using a fluorescent microscope (200×). S. grandilobata, 1; S. parva, 2; S. triangula, 3; S. scabra, 4; S. nanolobata, 5; and S. gibberosa, 6.
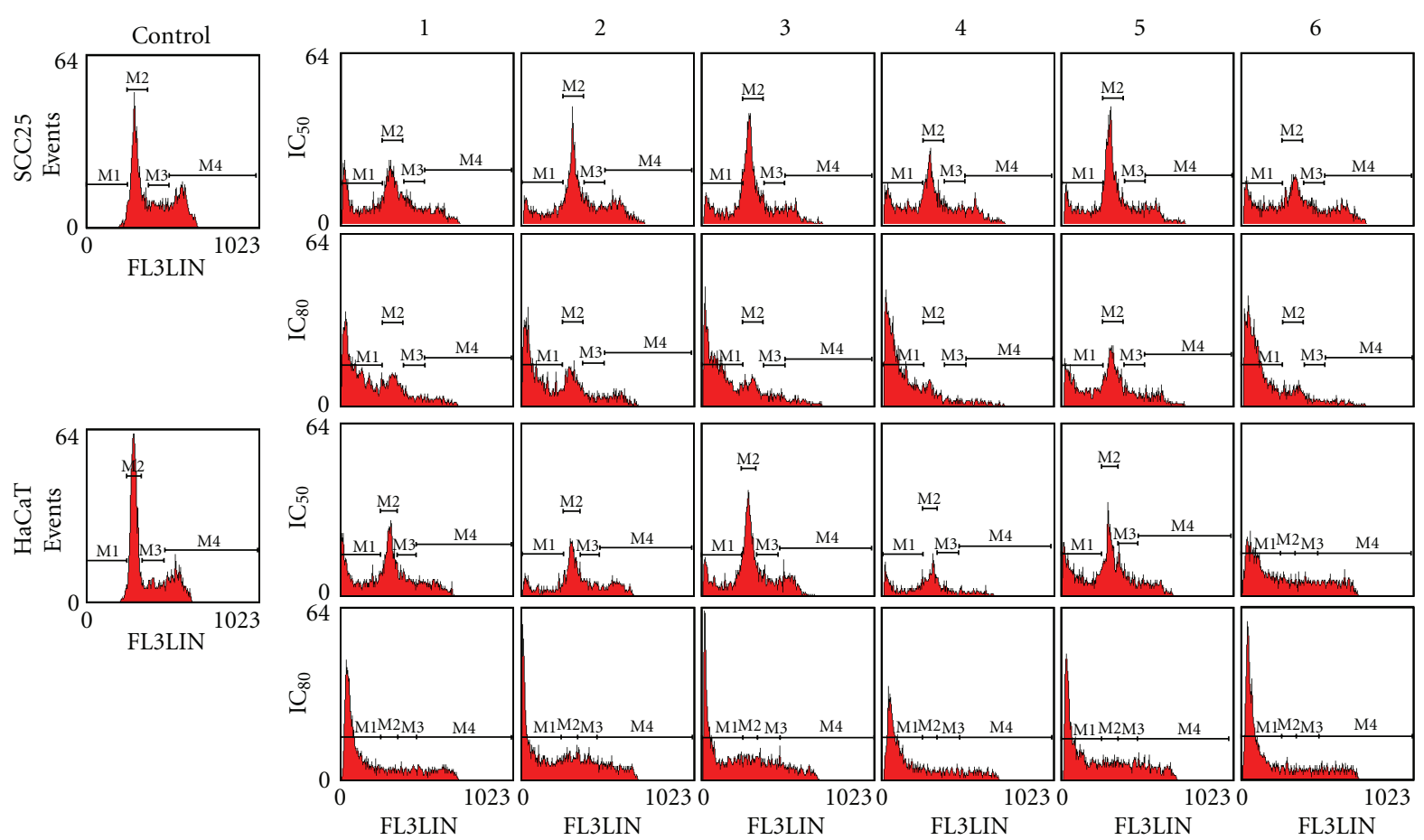

FIGURE 3: Effect of the genus Sinularia extracts on SCC25 and HaCaT cells apoptosis. Flow cytometric analysis of the cell cycle distribution of cells after treatment with extracts $\left(\mathrm{IC}_{50}\right.$ and $\mathrm{IC}_{80}$ ) for 18 hours as described in Materials and Methods. S. grandilobata, $1 ;$ S. parva, 2; S. triangula, 3; S. scabra, 4; S. nanolobata, 5 and S. gibberosa, 6. 
The previously characterized genus Sinularia of secondary metabolites is mainly chemicals that are structurally related to terpenoids. Previous studies have indicated that sinugrandisterols A-D, trihydroxysteroids, and oxygenated terpenoids from the $S$. grandilobata impede the proliferation of different cancer cell lines, such as human liver carcinoma (HepG2 and Hepa59T/VGH), human breast cancer cells (MCF-7 and MDA-MB-231), human oral epidermoid carcinoma (KB), and human lung cancer cells (A549) [16]. Three norcembrane-base diterpenoids, leptocladolide A, 1epi-leptocladolide A, 7E-leptocladolide A and ineleganoid were isolated from Taiwanese soft coral S. parva, and these compounds have been revealed to exhibit significant cytotoxic activity against KB and Hepa59T/VGH cancer cell line [17]. Four amphilectane-type diterpenoids, sinulobatins A-D [18], two norsesquiterpenoids, nanonorcaryophyllenes $\mathrm{A}-\mathrm{B}$, two diterpenoids, nanolobatins $\mathrm{A}-\mathrm{B}$, nordoterpenoids nanolobatin $\mathrm{C},(+)$-5-hydroxymethyl-5-methylfuran-2-one, and (+)-5-acetoxymethyl-5-methylfuran-2-one were isolated from the S. nanolobata. Sinulobatins A-D and nanolobatins $\mathrm{A}-\mathrm{B}$ exhibited moderate cytotoxicity against $\mathrm{KB}$ cancer cells. Nanonorcaryophyllenes A-B and nanolobatin C demonstrated no significant cytotoxicity against the tested cell lines, such as KB cells [19]. Additionally, previous reports have shown that polyoxygenated sterols from the formosan soft coral Sinularia gibberosa significantly inhibit the upregulation of the proinflammatory inducible nitric oxide synthase (iNOS) and cyclooxygenase-2 (COX-2) proteins of LPS (lipopolysaccharide)-stimulated RAW264.7 macrophage cells and cytotoxic activity against HepG2 (human liver carcinoma), MCF-7, MDA-MB-23 (human breast carcinoma), and A549 (human lung carcinoma) cells [20]. Extracts of soft corals Sinularia compressa have been adopted to explore the antibacterial potential of Bacillus pumilus and Pseudomonas vesicularis [21]. In this work, cell adhesion and cytotoxicity assay indicated that soft corals of the genus Sinularia extracts prevented SCC25 and HaCaT cell growth in a concentrationdependent manner. Moreover, the extracts of $S$. parva and $S$. nanolobata were found to be more effective inhibitors of cell viability than S. grandilobata, S. triangula, S. scabra, and S. gibberosa, suggesting the $S$. parva and $S$. nanolobata extracts could be investigated in the further to forage for a potential antioral cancer compounds. In the previous research, it was found that cembranoids extracted from $S$. parva and $S$. nanolobata showed cytotoxicity in some cell lines [17-19]. Nevertheless, the intrinsic structure and properties of these six soft corals are still not to be clarified. Additionally, the relation yield of compounds purified form soft corals is too few to carry out apoptosis experiments. This study is a preliminary test for cytotoxic activity of soft corals, and very few correlated researches could be found. At least, these results could provide the useful information to determine whether it is worthy to further isolate the natural product or not.

As previously reported, acylspermidines from the soft coral, Sinularia Sp. showed potent cytotoxicity against A431 cells [22] and NAKATA cells [23], and induced apoptotic DNA fragmentation and condensation of chromatin in A431 cells obtained from SCC [24]. In this study, morphologic alterations, nuclear chromatin condensation, and formation of apoptotic bodies indicate that extracts of soft corals of the genus Sinularia are cytotoxic. The cell cycle distribution demonstrates that extracts sensitized the cells in the $G_{0} / G_{1}$ and $G_{2} / M$ phases with a concomitant significant increase in the sub- $\mathrm{G}_{1}$ fraction. Experimental results of this work indicate that extracts from soft corals of the genus Sinularia kill not only SCC25, but also HaCaT cells through apoptosis. In summary, these studies demonstrate that the soft corals of the genus Sinularia extracts could be a warrant further research investigating the possible antioral cancer compounds in these medicinal marine organisms of soft corals.

\section{Acknowledgment}

The authors would like to thank the National Science Council of the Republic of China, Taiwan for financially supporting this research under contract no. NSC 95-2221-E-041-023.

\section{References}

[1] P. Radhika, P. R. Rao, J. Archana, and N. K. Rao, "Antiinflammatory activity of a new sphingosine derivative and cembrenoid diterpene (lobohedleolide) isolated from marine soft corals of Sinularia crassa TIXIER-DURIVAULT and Lobophytum species of the andaman and nicobar islands," Biological \& Pharmaceutical Bulletin, vol. 28, no. 7, pp. 13111313, 2005.

[2] G. D. Ruggieri, "Drugs from the sea," Science, vol. 194, no. 4264, pp. 491-497, 1976.

[3] D. J. Faulkner, "Marine natural products," Natural Product Reports, vol. 19, no. 1, pp. 1-49, 2002.

[4] D. J. Faulkner, "Marine natural products," Natural Product Reports, vol. 18, no. 1, pp. 1-49, 2001.

[5] J. C. Coll, B. F. Bowden, D. M. Tapiolas, et al., "Studies of australian soft corals-XXXV the terpenoid chemistry of soft corals and its implications," Tetrahedron, vol. 41, no. 6, pp. 1085-1092, 1985.

[6] C.-Y. Duh, S.-K. Wang, M.-J. Chu, and J.-H. Sheu, "Cytotoxic sterols from the soft coral Nephthea erecta," Journal of Natural Products, vol. 61, no. 8, pp. 1022-1024, 1998.

[7] T. L. Aceret, J. C. Coll, Y. Uchio, and P. W. Sammarco, "Antimicrobial activity of the diterpenes flexibilide and sinulariolide derived from Sinularia flexibilis Quoy and Gaimard 1833 (Coelenterata: Alcyonacea, Octocorallia)," Comparative Biochemistry and Physiology Part C, vol. 120, no. 1, pp. 121126, 1998.

[8] M. A. Rashid, K. R. Gustafson, and M. R. Boyd, "HIVinhibitory cembrane derivatives from a Philippines collection of the soft coral Lobophytum species," Journal of Natural Products, vol. 63, no. 4, pp. 531-533, 2000.

[9] A. S. R. Anjaneyulu, P. M. Gowri, and M. V. R. Krishna Murthy, "New sesquiterpenoids from the soft coral Sinularia intacta of the Indian Ocean," Journal of Natural Products, vol. 62, no. 12, pp. 1600-1604, 1999.

[10] J. Su, R. Yang, Y. Kuang, and L. Zeng, "A new cembranolide from the soft coral Sinularia capillosa," Journal of Natural Products, vol. 63, no. 11, pp. 1543-1545, 2000. 
[11] G.-H. Wang, J.-H. Sheu, C.-Y. Duh, and M. Y. Chiang, "Pachyclavulariaenones D-G, new diterpenoids from the soft coral Pachyclavularia violacea," Journal of Natural Products, vol. 65, no. 10, pp. 1475-1478, 2002.

[12] W. Chen, F.-Y. He, and Y.-Q. Li, "The apoptosis effect of hispolon from Phellinus linteus (Berkeley \& Curtis) Teng on human epidermoid KB cells," Journal of Ethnopharmacology, vol. 105, no. 1-2, pp. 280-285, 2006.

[13] J. Mork, "Forty years of monitoring head and neck cancer in Norway: no good news," Anticancer Research, vol. 18, no. 5B, pp. 3705-3708, 1998.

[14] L. Lopéz, M. A. Villavicencio, A. Albores, et al., "Cupressus lusitanica (Cupressaceae) leaf extract induces apoptosis in cancer cells," Journal of Ethnopharmacology, vol. 80, no. 2-3, pp. 115-120, 2002.

[15] T. Tamatani, M. Azuma, K. Motegi, N. Takamaru, Y. Kawashima, and T. Bando, "Cepharanthin-enhanced radiosensitivity through the inhibition of radiation-induced nuclear factor- $\kappa \mathrm{B}$ activity in human oral squamous cell carcinoma cells," International Journal of Oncology, vol. 31, no. 4, pp. 761-768, 2007.

[16] T. García-Gasca, V. Paz-González, M. C. Moncada-Álvarez, A. Blanco-Labra, and L. A. Salazar-Olivo, "Colorimetric quantitation of in vitro cell density using carmine, a chromosomespecific stain," Toxicology in Vitro, vol. 16, no. 5, pp. 573-579, 2002.

[17] A. F. Ahmed, S.-H. Tai, Y.-C. Wu, and J.-H. Sheu, "Sinugrandisterols A-D, trihydroxysteroids from the soft coral Sinularia grandilobata," Steroids, vol. 72, no. 4, pp. 368-374, 2007.

[18] A. F. Ahmed, R.-T. Shiue, G.-H. Wang, C.-F. Dai, Y.-H. Kuo, and J.-H. Sheu, "Five novel norcembranoids from Sinularia leptoclados and S. parva," Tetrahedron, vol. 59, no. 37, pp. 7337-7344, 2003.

[19] K. Yamada, T. Ujiie, K. Yoshida, T. Miyamoto, and R. Higuchi, "Sinulobatins A-D, new amphilectane-type diterpenoids from the Japanese soft coral Sinularia nanolobata," Tetrahedron, vol. 53, no. 13, pp. 4569-4578, 1997.

[20] A. F. Ahmed, J.-H. Su, R.-T. Shiue, et al., "New $\beta$ caryophyllene-derived terpenoids from the soft coral Sinularia nanolobata," Journal of Natural Products, vol. 67, no. 4, pp. 592-597, 2004.

[21] A. F. Ahmed, Y.-T. Hsieh, Z.-H. Wen, Y.-C. Wu, and J.-H. Sheu, "Polyoxygenated sterols from the Formosan soft coral Sinularia gibberosa," Journal of Natural Products, vol. 69, no. 9, pp. 1275-1279, 2006.

[22] S. H. Bhosale, V. L. Nagle, and T. G. Jagtap, "Antifouling potential of some marine organisms from India against species of Bacillus and Pseudomonas," Marine Biotechnology, vol. 4, no. 2, pp. 111-118, 2002.

[23] R. N. Fabricant, J. E. De Larco, and G. J. Todaro, "Nerve growth factor receptors on human melanoma cells in culture," Proceedings of the National Academy of Sciences of the United States of America, vol. 74, no. 2, pp. 565-569, 1977.

[24] S. Miyauchi, T. Moroyama, S. Kyoizumi, J.-I. Asakawa, T. Okamoto, and K. Takada, "Malignant tumor cell lines produce interleukin-1-like factor," In Vitro Cellular \& Developmental Biology. Plant, vol. 24, no. 8, pp. 753-758, 1988. 

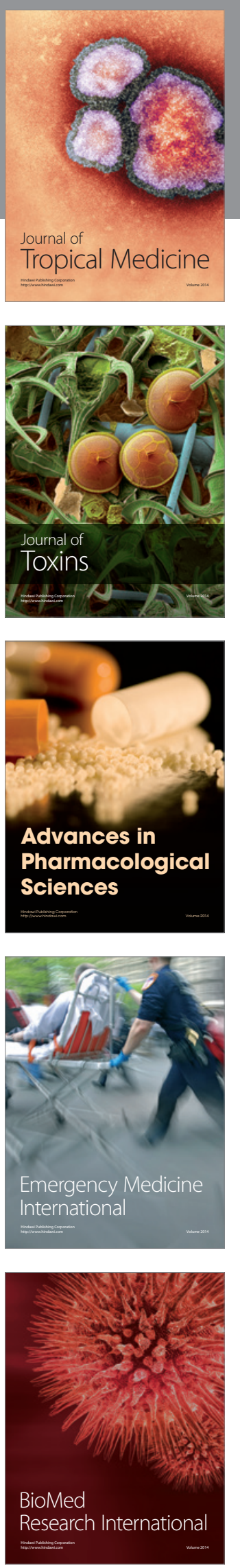
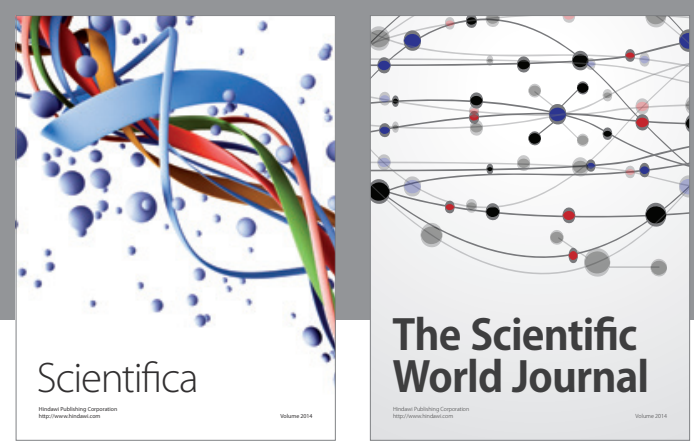

The Scientific World Journal
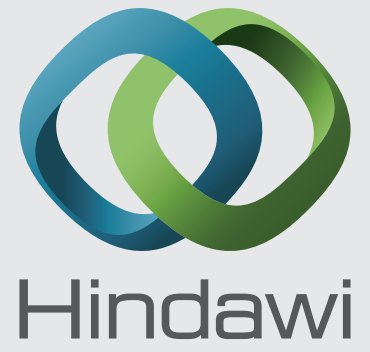

Submit your manuscripts at

http://www.hindawi.com
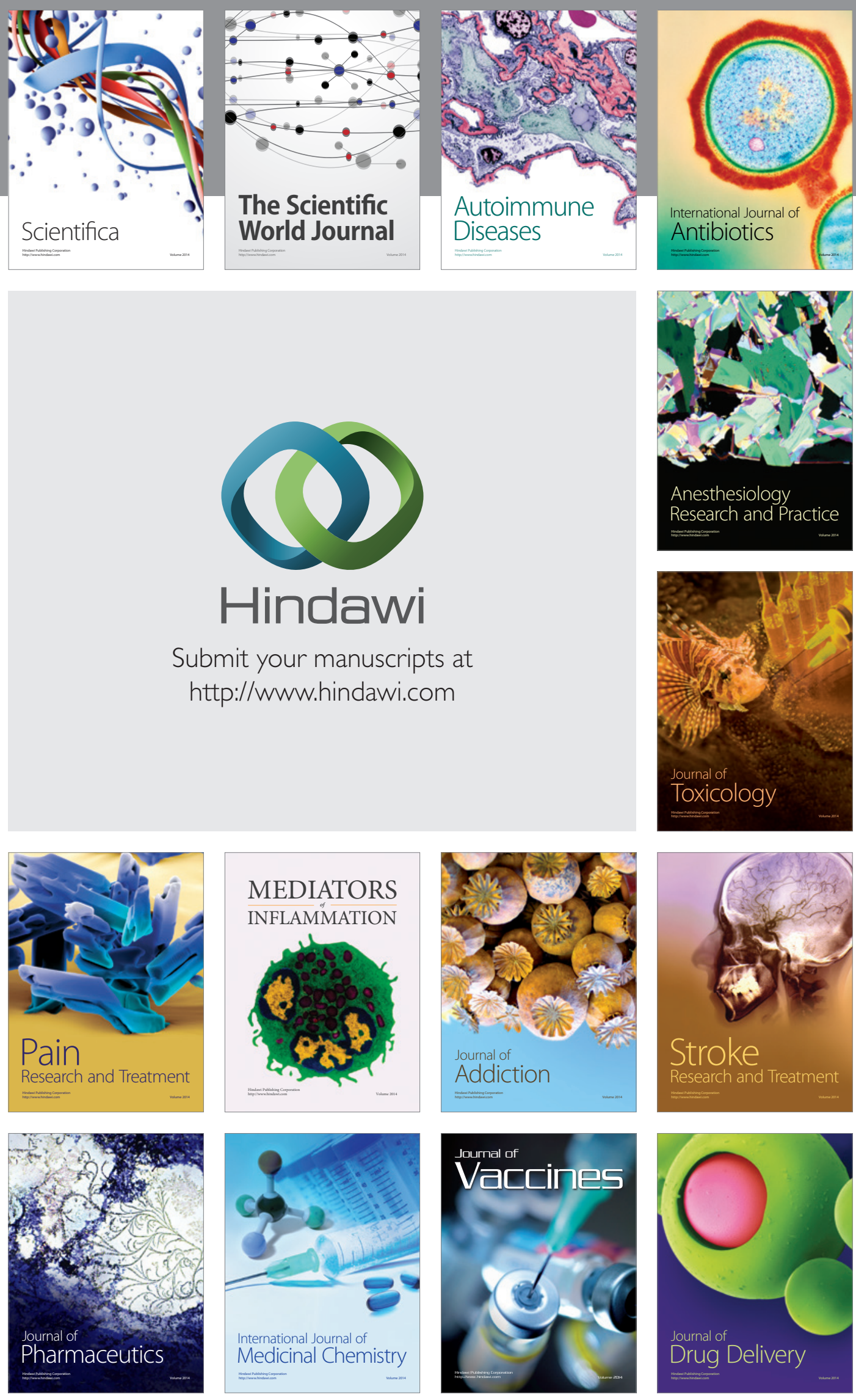